\title{
Possible involvement of inhibin in the interrelationship between numbers of antral follicles and peripheral FSH concentrations in female rats
}

\author{
R. Welschen, W. P. Hermans and F. H. de Jong* \\ Departments of Anatomy and ${ }^{*}$ Biochemistry (Division of Chemical Endocrinology), \\ Erasmus University, Rotterdam, The Netherlands
}

\begin{abstract}
Summary. The possible dependence of peripheral concentrations of FSH on a non-steroidal, ovarian factor, was studied in adult female rats. Increases in FSH levels during the periovulatory period were not correlated with decreases of steroid concentrations, and administration of steroids did not result in a reduction of FSH levels to basal values. However, a negative correlation between FSH levels and numbers of large follicles (volume $\geqslant 200 \times 10^{5} \mu \mathrm{m}^{3}$ ) was demonstrated, and injection of steroid-free bovine follicular fluid, which contains inhibin-like activity, suppressed FSH levels to basal values.

These results suggest that an ovarian, inhibin-like factor is involved in the fast regulation of $\mathrm{FSH}$ concentrations in the periovulatory period, and that this inhibin-mediated control of FSH might play a role in the regulation of the number of follicles maturing in female rats.
\end{abstract}

\section{Introduction}

Campbell \& Schwartz (1977) provided evidence that in adult female rats the control of pituitary secretion of follicle-stimulating hormone (FSH) may differ from that of luteinizing hormone $(\mathrm{LH})$. Secretion of FSH, but not of $\mathbf{L H}$, is greatly enhanced about 5-12 h after unilateral ovariectomy (Welschen \& Dullaart, 1974; Campbell, Schwartz \& Gorski-Firlit, 1977; Butcher, 1977; Welschen, Dullaart \& de Jong, 1978), or, in intact rats, immediately following the ovulatory surge of LH release (Gay, Midgley \& Niswender, 1970). Evidence is accumulating that in such circumstances the rise of FSH secretion is not dependent on a drop in peripheral levels of ovarian steroid hormones. In studies on steroid levels after unilateral ovariectomy there was no decrease of oestradiol levels during the first $24 \mathrm{~h}$ (Campbell et al., 1977; Butcher, 1977; Welschen et al., 1978). Only Chappel \& Barraclough (1977) found decreased oestradiol levels after ovariectomy at pro-oestrus in 4-day cyclic rats. However, replacement therapy with oestradiol (Chappel \& Barraclough, 1977; Butcher, 1977) was ineffective in preventing the acute rise in FSH levels after unilateral ovariectomy, whereas antiserum against oestradiol-17 $\beta$ injected into intact rats did not provoke such a rise (Butcher, 1977). Peripheral levels of progesterone were decreased immediately after unilateral ovariectomy, but adrenalectomy, resulting in decreased oestradiol and progesterone levels (Campbell et al., 1977), did not induce an acute rise in FSH secretion.

In 1932, McCullagh postulated that a non-steroidal, specifically FSH-suppressing substance, "inhibin", is secreted by the male gonad. There is considerable evidence for the existence of inhibin in male animals (see for reviews Baker et al., 1976; Setchell, Davies \& Main, 1977; 
Chari, 1977; de Jong, 1979), and inhibin-like activity has been detected in follicular fluid of cows (de Jong \& Sharpe, 1976; Hopkinson et al., 1977; Welschen, Hermans, Dullaart \& de Jong, 1977), sows (Marder, Channing \& Schwartz, 1977; Welschen et al., 1977), women (Daume, Chari, Hopkinson, Sturm \& Hirschhäuser, 1978), and mares (Miller, Wesson \& Ginther, 1979), and might play an important role in the regulation of FSH secretion in the female animal (Marder et al., 1977; Schwartz \& Channing, 1977; Welschen et al., 1978). Inhibin-like activity in bovine follicular fluid and in medium from cultured rat Sertoli cells suppresses the unstimulated release of FSH but not of LH from cultured pituitary cells in parallel ways (de Jong, Smith \& van der Molen, 1979).

The present paper describes experiments investigating the involvement of inhibin-like activity in the regulation of FSH secretion by the pituitary gland during the periovulatory period of rats.

\section{Materials and Methods}

Animals. Adult female rats of a Wistar substrain (R-Amsterdam) were kept under controlled conditions of light (light period 05:00-19:00 h) and temperature $\left(22-24^{\circ} \mathrm{C}\right.$ ) and received standard dry pellets and tap water ad libitum. Daily vaginal smears were taken and only rats with 2 consecutive 5-day cycles before the cycle of treatment were used.

Follicular fluid. Cow ovaries were obtained at a local slaughterhouse, and follicular fluid was aspirated from follicles of $10-20 \mathrm{~mm}$ diameter immediately after collection of the ovaries. The bovine follicular fluid was stirred with charcoal $(50 \mathrm{mg} / \mathrm{ml})$ at $21 \pm 1^{\circ} \mathrm{C}$ for $60 \mathrm{~min}$ and centrifuged at $10000 \mathrm{~g}$ for $30 \mathrm{~min}$. After treatment, concentrations $(\mathrm{ng} / \mathrm{ml})$ of oestradiol $-17 \beta$ $(0.04)$ and progesterone $(0.33)$ were $<1 \%$ of the original concentrations (103 and 150 respectively).

Bovine plasma was used as control fluid because it has a protein composition similar to that of follicular fluid (Caravaglios \& Cilotti, 1957). Injections of bovine follicular fluid and bovine plasma were given intraperitoneally.

Experiments. All operations, injections and blood collections were performed under light ether anaesthesia. Animals were bled by puncture of the ophthalmic venous plexus. At least 6 rats were used in all groups of control and experimental animals unless otherwise stated. Details of the experiments are given in 'Results'.

Hormone determinations. Serum FSH and $\mathrm{LH}$ concentrations were estimated by radioimmunoassay (RIA) as described previously (Welschen et al., 1975). All results are expressed in terms of NIAMDD-rat-FSH-RPI and NIAMDD-rat-LH-RP1. Inter-assay variability (coefficients of variation) was $16 \%$ for $\mathrm{FSH}$ and $14 \%$ for $\mathrm{LH}$.

Oestradiol, progesterone and testosterone were assayed by radioimmunoassay as described by de Jong, Hey \& van der Molen (1973), de Jong, Baird \& van der Molen (1974) and Verjans, Cooke, de Jong, de Jong \& van der Molen (1973). Results were corrected for recovery after extraction and chromatography on $\mathrm{LH}-20$ microcolumns. The latter technique was used for the assay of oestradiol and testosterone. The detection limits of the various assays, defined as the blank + twice the standard deviation at the level of the blank, were 5 (oestradiol) and 10 (progesterone and testosterone) $\mathrm{pg} /$ tube. Interassay variability, calculated from repeated results of pooled plasma samples, varied between 10 and $15 \%$. The main cross-reacting steroids in these assays were dihydrotestosterone ( $60 \%$, expressed as (mass of 'measured steroid' suppressing $\% \mathrm{~B}$ to $50 \%$ of $\mathrm{B}_{0} /$ mass of cross-reacting steroid causing the same suppression) $\times 100 \%$ ) in the testosterone assay; oestrone (3\%) and oestriol $(5 \%)$ in the oestradiol assay and $11 \beta$ hydroxyprogesterone $(17 \%)$ in the progesterone assay.

Follicle counts. Follicles were counted in ovarian sections of $5 \mu \mathrm{m}$ after routine histological procedures (fixation in Bouin's fluid, staining with haematoxylin and eosin). Follicles were classified using the method of Boling, Blandau, Soderwall \& Young $(1941)$, , as slightlys modified $A \mathrm{~A}$ 
by Welschen (1973). The volume classes correspond with a mean follicle diameter and with the stage numbers used by Mandl \& Zuckerman (1952) approximately in the following way: $200-499 \times 10^{5} \mu \mathrm{m}^{3}$ with $350-450 \mu \mathrm{m}$ and stages 3 and $4 ; \geqslant 500 \times 10^{5} \mu \mathrm{m}^{3}$ with $\geqslant 450 \mu \mathrm{m}$ and stages 5 to 8 .

Statistics. For statistical analysis of results the Student's $t$ test or the Wilcoxon two-sample test were used. A difference was considered as statistically significant when the double-tail probability was $<0.05$.

\section{Results}

The interrelationship between inhibin-like activity and ovarian steroid hormones on the one hand, and gonadotrophin levels and numbers of antral follicles during pro-oestrus and oestrus on the other were studied in 2 experiments to investigate the effect of bovine follicular fluid on the secondary rise of FSH at pro-oestrus.

\section{Experiment 1}

Rats were killed and bled at 4-h intervals between 12:00 $\mathrm{h}$ on the day of pro-oestrus and 16:00 $\mathrm{h}$ on the day of oestrus. Serum and plasma were used for FSH, LH, oestradiol,
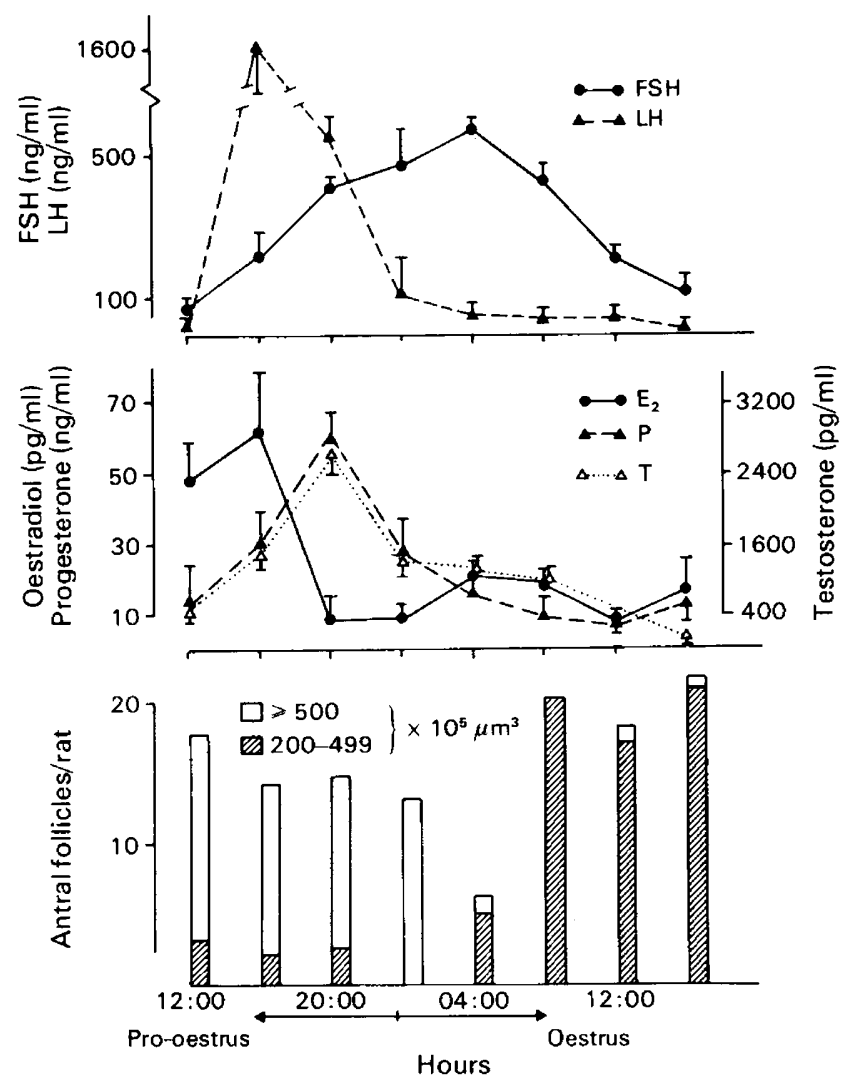

Text-fig. 1. Peripheral levels (mean \pm s.e.m.) of FSH, LH, oestradiol-17 $\beta\left(\mathrm{E}_{2}\right)$, progesterone (P) and testosterone $(\mathrm{T})$ and numbers of follicles $\geqslant 200 \times 10^{5} \mu \mathrm{m}^{3}$ in adult female rats $(\mathrm{N}=5)$ between $12: 00 \mathrm{~h}$ on the day of pro-oestrus and 16:00 $\mathrm{h}$ on the day of oestrus. 
progesterone and testosterone determinations and ovaries were fixed in Bouin's fluid for follicle counts. The results are given in Text-fig. 1. All hormone concentrations followed the well-known patterns (see Gay \& Tomacari, 1974; Nequin, Alvarez \& Schwartz, 1975), although the absolute values of testosterone appeared considerably lower than those reported by Gay \& Tomacari (1974). Ovulation apparently occurred in all follicles $\geqslant 500 \times 10^{5} \mu \mathrm{m}^{3}$ between 00:00 and $04: 00 \mathrm{~h}$ on the day of oestrus. A new group of follicles with a well-developed antrum (size class $\geqslant 200 \times 10^{5} \mu \mathrm{m}^{3}$ ) was observed from 04:00 $\mathrm{h}$ on the day of oestrus onwards. During the period between 12:00 h on the day of pro-oestrus and 16:00 h on the day of oestrus there was a significant negative correlation between mean numbers of follicles in this size class and mean peripheral FSH levels $(r=-0.65, n=8, P<0.05)$.

\section{Experiment 2}

At 14:00 h on the day of pro-oestrus the rats received $500 \mu \mathrm{l}$ bovine follicular fluid or plasma/ $100 \mathrm{~g}$ body weight or 3 silicone-tube implants that were empty or contained oestradiol, progesterone or testosterone. The lengths and outer diameter of the tubings were 5 and $1.4 \mathrm{~mm}$ for oestradiol; $5 \mathrm{~cm}$ and $3.8 \mathrm{~mm}$ for progesterone; and 5 and $3.8 \mathrm{~mm}$ for testosterone. Oestradiol and testosterone were mixed 1:10 with cholesterol $(\mathrm{w} / \mathrm{w})$. The tubings were placed in phosphate-buffered saline, $\mathrm{pH} 7 \cdot 2$, overnight before implantation. The rats were bled and killed at $04: 00 \mathrm{~h}$ and 12:00 $\mathrm{h}$ on the day of oestrus for hormone determinations and follicle counts. Of

Table 1. Influence of administration of steroid hormones or bovine follicular fluid on mean \pm s.e.m. peripheral levels of FSH and LH and on number's of antral follicles at early oestrus

\begin{tabular}{|c|c|c|c|c|c|}
\hline \multirow{2}{*}{$\begin{array}{c}\text { Treatment at } 14: 00 \mathrm{~h} \text { on day } \\
\text { of pro-oestrus }\end{array}$} & \multirow{2}{*}{$\begin{array}{l}\text { Time of } \\
\text { autopsy } \\
\text { (h) on } \\
\text { day of } \\
\text { oestrus }\end{array}$} & \multirow{2}{*}{$\begin{array}{l}\text { No. of } \\
\text { rats }\end{array}$} & \multicolumn{2}{|c|}{ Hormone conc. $(\mathrm{ng} / \mathrm{ml})$} & \multirow{2}{*}{$\begin{array}{c}\text { No. of } \\
\text { follicles } \\
\geqslant 200 \times 10^{5} \mu \mathrm{m}^{3} \\
\text { per ovary }\end{array}$} \\
\hline & & & FSH & LH & \\
\hline $\begin{array}{l}\text { Controls ( } 3 \text { empty tubes }+ \\
\text { bovine plasma) }\end{array}$ & $\begin{array}{l}04: 00 \\
12: 00\end{array}$ & $\begin{array}{l}8 \\
8\end{array}$ & $\begin{array}{l}394 \pm 29 \\
274 \pm 19\end{array}$ & $\begin{array}{l}82 \pm 4 \\
45 \pm 6\end{array}$ & $\begin{array}{r}2 \cdot 0 \pm 0 \cdot 7 \\
11 \cdot 5 \pm 2 \cdot 5\end{array}$ \\
\hline Steroid implants $\dagger$ (see text) & $\begin{array}{l}04: 00 \\
12: 00\end{array}$ & $\begin{array}{l}7 \\
8\end{array}$ & $\begin{array}{l}328 \pm 13 \\
249 \pm 25\end{array}$ & $\begin{array}{l}41 \pm 5^{*} \\
32 \pm 11\end{array}$ & $\begin{array}{l}4.5 \pm 1.3 \\
8.6 \pm 0.6\end{array}$ \\
\hline $\begin{array}{l}\text { Bovine follicular fluid } \\
\qquad(500 \mu \mathrm{l} / 100 \mathrm{~g} \text { body } \mathrm{wt})\end{array}$ & $\begin{array}{l}04: 00 \\
12: 00\end{array}$ & $\begin{array}{l}7 \\
7\end{array}$ & $\begin{array}{c}54 \pm 2^{*} \\
136 \pm 17^{*}\end{array}$ & $\begin{array}{l}52 \pm 14 \\
52 \pm 8\end{array}$ & $\begin{array}{l}1 \cdot 7 \pm 0.4 \\
4 \cdot 5 \pm 0.5^{*}\end{array}$ \\
\hline
\end{tabular}

+ Mean of 2 determinations in pooled plasma of control rats and implant-bearing rats at $04: 00 \mathrm{~h}$ at oestrus: 220 and $3750 \mathrm{pg}$ testosterone $/ \mathrm{ml}$; not determined and $831 \mathrm{pg}$ oestradiol $/ \mathrm{ml}$; and 12 and $53 \mathrm{ng} \mathrm{progesterone} / \mathrm{ml}$ respectively.

${ }^{*} P<0.05$ compared with corresponding control values.

Table 2. Influence of administration of testosterone by means of an implant placed subcutaneously or on the surface of each ovary on mean \pm s.e.m. plasma concentrations of FSH and numbers of antral follicles at oestrus

\begin{tabular}{|c|c|c|c|}
\hline \multirow[b]{2}{*}{$\begin{array}{c}\text { Treatment at } 14: 00 \mathrm{~h} \text { on day of } \\
\text { pro-oestrus }\end{array}$} & \multirow[b]{2}{*}{$\begin{array}{l}\text { No. of } \\
\text { rats }\end{array}$} & \multicolumn{2}{|c|}{ At autopsy at $16: 00 \mathrm{~h}$ on day of oestrus } \\
\hline & & FSH $(\mathbf{n g} / \mathrm{ml})$ & $\begin{array}{c}\text { No. of follicles } \\
\geqslant 200 \times 10^{5} \mu \mathrm{m}^{3} / \mathrm{ovary}\end{array}$ \\
\hline Control & 10 & $188 \pm 8$ & $11.8 \pm 0.6$ \\
\hline Implant, subcutaneous & 9 & $282 \pm 18^{*}$ & $9 \cdot 0 \pm 1 \cdot 4$ \\
\hline Implant, on ovarian surface & 9 & $559 \pm 29^{*}$ & $5 \cdot 0 \pm 0.8^{*}$ \\
\hline
\end{tabular}

Mean of 2 determinations of testosterone concentrations $(\mathrm{pg} / \mathrm{ml})$ in pooled plasma at $04: 00 \mathrm{~h}$ on day of oestrus was 720 for controls, 3050 for s.c. implants and 3140 for implants on the ovarian surface.

${ }^{*} P<0.05$ compared with values in both other groups. 
these treatments only injection of bovine follicular fluid (Table 1) resulted in a significant suppression of FSH levels at 04:00 h and 12:00 h on the day of oestrus and in decreased numbers of follicles with a volume of $200-500 \times 10^{5} \mu \mathrm{m}^{3}$, but there was no effect on the occurrence of ovulation or on LH levels.

Silicone tubes containing testosterone (length $4 \mathrm{~mm}$, o.d. $1.4 \mathrm{~mm}$ ) were implanted either inside the bursa ovarica on the ovarian surface or subcutaneously. The position of the implants was confirmed at autopsy. Implants resulted in peripheral testosterone concentrations of about 4 times those found in control rats (Table 2); the implants on the ovarian surface produced significantly increased FSH levels at 16:00 h on the day of oestrus, and significantly decreased numbers of antral follicles. Implants placed s.c. induced only a marginal increase of serum FSH levels.

\section{Discussion}

The present results support the hypothesis that in the female rat the ovaries can exert an inhibitory feed-back on the pituitary secretion of FSH via inhibin-like activity during the periovulatory period. The inverse relationship between FSH levels and numbers of follicles of volume $\geqslant 200 \times 10^{5} \mu^{3}$ suggests that these follicles secrete inhibin-like activity. Furthermore, antral follicles seem to limit their own number by the inhibin-feedback on FSH secretion.

In the adult female rat injection of inhibin-like material in a dose that causes maximal suppression of FSH levels appears to exert short-term effects on FSH secretion only (de Jong, Welschen, Hermans, Smith \& van der Molen, 1978; DePaolo, Wise, Anderson, Barraclough \& Channing, 1979; DePaolo, Hirshfield, Anderson, Barraclough \& Channing, 1979). Probably inhibin-like activity is inactivated and removed from its target organ within a few hours. If so, changes in inhibin secretion from the ovary may be expected to be followed with a short latency by short-lived changes in FSH secretion.

Since inhibin-like activity has been defined as a factor which specifically suppresses FSH levels (de Jong, 1979) whereas steroid hormones (depending on the dose and time of treatment) influence both FSH and LH secretion, the involvement of inhibin-like activity in diverging changes of FSH and LH levels was studied in the present experiments. In the rat the second phase of FSH release about the time of ovulation occurs in the absence of a high level of LH release (Gay et al., 1970). This second phase of FSH release can be prevented by injection of antiserum to testosterone (Gay \& Tomacari, 1974), and was explained as reflecting a facilitatory effect of endogenous testosterone on FSH secretion. The second phase of FSH release can also be prevented by injection of steroid-free follicular fluid (Schwartz \& Channing, 1977). The results of the present experiments confirm these latter data. In addition, they demonstrate that increased levels of oestradiol, progesterone and testosterone cannot prevent the second phase of the FSH surge. Thus, if this second phase is induced by diminished inhibitory feedback from the ovary on FSH secretion, it must be due to a relative lack of ovarian release of inhibin-like activity and not to a lack of steroid hormones. Schwartz \& Channing (1977) suggest that after a pro-oestrus or an artificial LH stimulus, the oocyte-follicular complex is altered, resulting in secretion of decreased amounts and/or chemically altered inhibin. The second phase of FSH release, thus induced, recruits - as the present experiment shows-a new cohort of follicles of $\geqslant 200 \times 10^{5} \mu^{3}$ in size (see also Schwartz, 1969; Welschen \& Dullaart, 1976). Furthermore, this cohort of antral follicles, once recruited, seems to suppress FSH secretion to baseline values.

The data from the testosterone-implant experiment seem to confirm the above observations: a subcutaneous implant did not result in decreased numbers of follicles and did not prolong the second phase of FSH release, whereas implants on the ovarian surface did. Androgens produced in the ovary in response to hCG have been shown to act locally to inhibit the effect of oestrogen on follicular growth (Louvet, Harman, Schreiber \& Ross, 1975) It therefore seems likely that 
testosterone implants on the ovary, instead of exerting a direct facilitatory effect on FSH release, have inhibited the growth of follicles to the antral stage and thus the secretion of sufficiently large amounts of inhibin to suppress FSH to baseline values. Assuming that this really is the case, the decreased FSH levels found by Gay \& Tomacari (1974) after injection of antiserum against testosterone might reflect increased follicle growth and a greater inhibin feedback rather than a reduced direct stimulatory effect of testosterone on FSH release, although such a stimulatory effect has been shown to exist in certain circumstances (Drouin \& Labrie, 1976; Juneja, Motta, Vasconi \& Martini, 1977; Labrie et al., 1978).
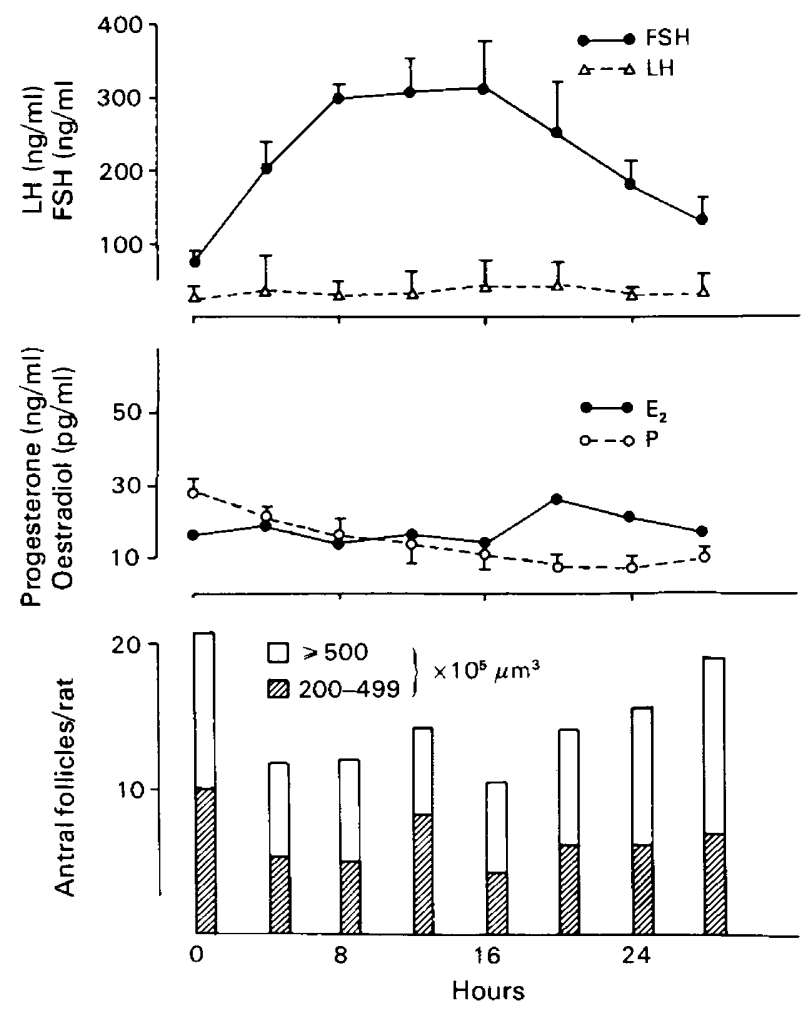

Text-fig. 2. Peripheral levels of FSH, LH, progesterone (mean \pm s.e.m. for 5-6 samples) and oestradiol-17 $\beta$ (mean of 2-3 determinations in pooled plasma) and mean numbers of antral follicles $\geqslant 200 \times 10^{5} \mu \mathrm{m}^{3}$ in adult female rats $0-28 \mathrm{~h}$ after unilateral ovariectomy at 09:00 h on Day 2 of dioestrus. Throughout the experimental period, FSH and LH values in control animals ranged between 50 and $100 \mathrm{ng} \mathrm{FSH} / \mathrm{ml}$ and between 10 and $30 \mathrm{ng} \mathrm{LH} / \mathrm{ml}$ (Welschen et al., 1978).

The results of experiments with unilaterally ovariectomized rats also strongly suggest that in other circumstances regulation of FSH levels may occur via inhibin-like activity secreted by antral follicles (Welschen et al., 1978). For comparison these data have been reproduced in Text-fig. 2 and the similarity of the temporal relationship between levels of FSH, LH, steroid hormones and numbers of follicles in (pro)oestrous and in unilaterally ovariectomized rats (Text-figs 1 and 2) is clear. In both cases a decrease of high concentrations of FSH to basal levels is inversely correlated with increasing numbers of healthy follicles $\geqslant 200 \times 10^{5} \mu \mathrm{m}^{3}$ to about 25/animal (correlation between mean numbers of follicles and mean peripheral FSH levels in unilaterally ovariectomized rats: $r=-0.81, n=8, P<0.05$ ). In normal cyclic rats this number of 25 follicles/animal is never exceeded; smaller numbers (about 15/rat) are only found during the last days of the cycle. At that time, the mean diameter is greatly increased, resulting in 
a total number of granulosa cells similar to that present in 25 small follicles during the first days of the cycle (for data on granulosa cell numbers see Hage, Groen-Klevant \& Welschen, 1978). This suggests that inhibin is produced predominantly by granulosa cells of antral follicles in vivo, as has been shown by Erickson \& Hsueh (1978) with in-vitro experiments, and is also supported by data of Welschen et al. (1977) and of Becker, Klupp, Epstein, Seidl \& Lunenfeld (1977) who showed that, at least in the cow, medium-sized and large antral follicles contain the highest concentration of inhibin-like activity. The inhibin-feedback mechanism may therefore be involved in the regulation of the number of follicles $\geqslant 200 \times 10^{5} \mu \mathrm{m}^{3}$ in size which are to ovulate or to become atretic during each cycle.

A similar control might also exist in the period characterized by the first growth of antral follicles, from Day 21 of life onwards. During this period, the pituitary gland becomes sensitive to inhibin-like activity as present in bovine follicular fluid (Hermans, van Leeuwen, Debets \& de Jong, 1980). Levels of FSH, LH, oestradiol and progesterone and the number of follicles $\geqslant 200 \times$ $10^{5} \mu \mathrm{m}^{3}$, as reported by various workers, reveal time relationships as shown in Text-fig. 3. After the dramatic fall in FSH levels around Day 20, there is a further decrease of FSH levels between 22 and 35 days of age. This decrease is not parallelled by increase of oestradiol levels and there is only a marginal increase of progesterone levels. Since injection of a steroid combination was
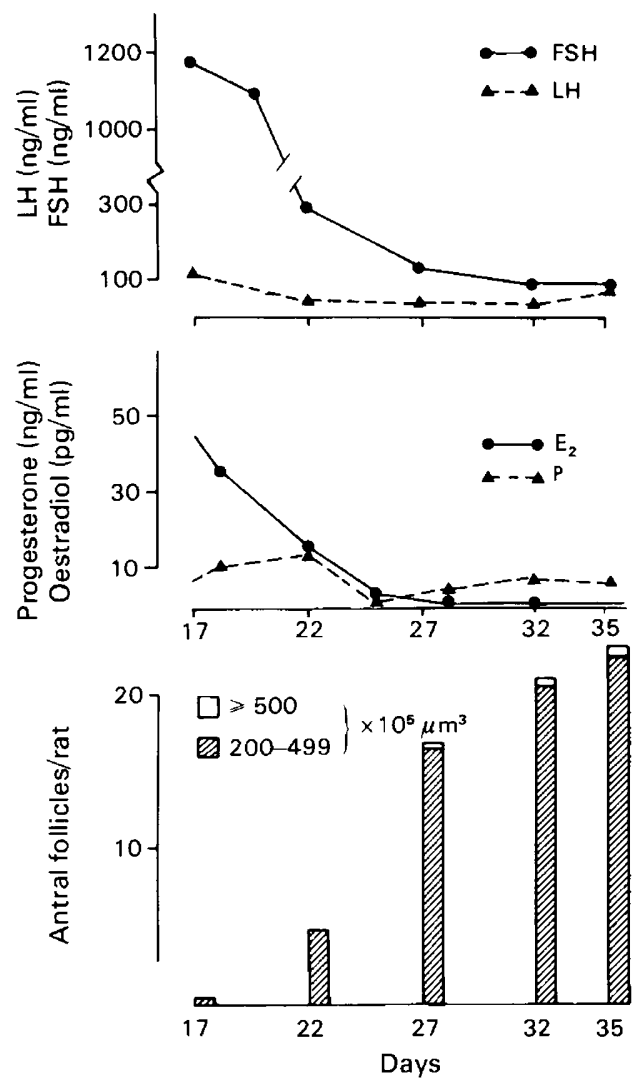

Text-fig. 3. Peripheral levels of FSH and LH (Ojeda \& Ramirez, 1972; Döhler \& Wuttke, 1975; Meijs-Roelofs, Uilenbroek, Osman, \& Welschen, 1973a) and of oestradiol-17ß (Meijs-Roelofs, Uilenbroek, de Jong \& Welschen, 1973b; Döhler \& Wuttke, 1975) and progesterone (Meijs-Roelofs, de Greef \& Uilenbroek, 1975; Döhler \& Wuttke, 1975) and numbers of follicles $\geqslant 200 \times 10^{5} \mu \mathrm{m}^{3}$ (Meijs-Roelofs et al., 1973a; and unpublished studies) in intact female rats between 17 and 35 days of age. 
only effective in suppressing FSH levels at 25 days of age and not at later ages (Hermans et al., 1980), the involvement of another factor in FSH regulation seems more likely. That this factor might be inhibin-like activity is suggested by the finding that the decrease of FSH levels finds its mirror image in the increase of the number of antral follicles (Text-fig. 3) and the finding that a rapid rise of $\mathrm{FSH}$ levels after ovariectomy occurs from 25 days of age onwards. This increase can be prevented by injection of steroid-free bovine follicular fluid (Hermans et al., 1980).

In combination, the present data seem to suggest that from the age of 25-35 days onwards the regulation of FSH secretion is (at least partly) under the control of ovarian inhibin secretion. Inhibin might be produced by the granulosa cells of antral follicles. The data suggest that in late prepubertal and adult female rats a number of granulosa cells, as present in about 25 antral follicles in the size range of $200-500 \times 10^{5} \mu \mathrm{m}^{3}$ or in smaller numbers of larger follicles, produce amounts of inhibin sufficient to maintain peripheral FSH concentrations at about $100 \mathrm{ng} / \mathrm{ml}$. This level of FSH seems sufficient to keep the number of healthy granulosa cells fairly constant. Any decrease in the number of inhibin-producing granulosa cells (or follicles) results in an enhanced pituitary secretion of FSH during at least 5-20 h after the decrease. The increased FSH levels then seem to stimulate granulosa cell proliferation to such an extent that the critical number required for inhibin levels sufficient to reduce FSH concentrations to basal values is reached.

\section{References}

Baker, H.W.G., Bremner, W.J., Burger, H.G., de Kretser, D.M., Dulmanis, A., Eddie, L.W., Hudson, B., Keogh, E.J., Lee, V.W.K. \& Rennie, G.C. (1976) Testicular control of follicle stimulating hormone secretion. Recent Progr. Horm. Res. 32, 429-476.

Becker, H., Klupp, M., Epstein, Y., Seidl, U. \& Lunenfeld, B. (1977) Follicle stimulating hormone inhibitory factor of male and female gonadal origin. Isr. J. Med. Sci. 13, 623.

Boling, J.L., Blandau, R.J., Soderwall, A.L. Young, W.C. (1941) Growth of graafian follicle and time of ovulation in the albino rat. Anat. Rec. 79, 313-331.

Butcher, R.L. (1977) Changes in gonadotrophins and steroids associated with unilateral ovariectomy of the rat. Endocrinology 101, 830-840.

Campbell, C.S. \& Schwartz, N.B. (1977) Steroid feedback regulation of luteinizing hormone and follicle stimulating hormone secretion rates in male and female rats. $J$. Toxicol. environ. Health 3, 61-95.

Campbell, C.S., Schwartz, N.B. \& Gorski-Firlit, M. (1977) The role of adrenal and ovarian steroids in the control of serum LH and FSH. Endocrinology 101, 162-172.

Caravaglios, R. \& Cilotti, R. (1957) A study of the proteins in the follicular fluid of the cow. J. Endocr. 15, 273-278.

Chappel, C.S. \& Barraclough, C.A. (1977) Further studies on the regulation of FSH secretion. Endocrinology 101, 24-31.

Chari, S. (1977) Chemistry and physiology of inhibin: a review. Endokrinologie 70, 99-107.

Daume, E., Chari, S., Hopkinson, C.R.N., Sturm, G. \& Hirschhäuser, C. (1978) Nachweis von InhibinAktivität in der Follikelflussigkeit menschlicher Ovarien. Klin. Wschr. 56, 369-370.

de Jong, F.H. (1979) Inhibin-fact or artifact. Molec. cell. Endocr. 13, 1-10. de Jong, F.H. \& Sharpe, R.M. (1976) Evidence for inhibin-like activity in bovine follicular fluid. Nature, Lond. 263, 71-72.

de Jong, F.H., Hey, A.H. \& van der Molen, H.J. (1973) Effects of gonadotrophins on the secretion of oestradiol-17 $\beta$ and testosterone by the rat testis. $J$. Endocr. 57, 277-284.

de Jong, F.H., Baird, D.T. \& van der Molen, H.J. (1974) Ovarian secretion rates of oestrogens, androgens and progesterone in normal women and in women with persistent ovarian follicles. Acta endocr., Copenh. 77, 575-587.

de Jong, F.H., Welschen, R., Hermans, W.P., Smith, S.D. \& van der Molen, H.J. (1978) Effects of testicular and ovarian inhibin-like activity, using in vitro and in vivo systems. Int. J. Androl., Suppl. 2, 125-138.

de Jong, F.H., Smith, S.D. \& van der Molen, H.J. (1979) Bioassay of inhibin-like activity using pituitary cells in vitro. J. Endocr. 80, 91-102.

DePaolo, L.V., Hirshfield, A.N., Anderson, L.D., Barraclough, C.A. \& Channing, C.P. (1979) Suppression of pituitary secretion of follicle stimulating hormone by porcine follicular fluid during pro-oestrus and oestrus in the rat: effects on gonadotrophin and steroid secretion, follicular development and ovulation during the following cycle. J. Endocr. 83, 355-368.

DePaolo, L.V., Wise, P.M., Anderson, L.D., Barraclough, C.A. \& Channing, C.P. (1979) Suppression of the pituitary follicle stimulating hormone secretion during proestrus and estrus in rats by porcine follicular fluid: possible site of action. Endocrinology 104, 402-408.

Döhler, K.D. \& Wuttke, W. (1975) Changes with age in levels of serum gonadotrophins, prolactin and gonadal steroids in prepubertai male and female rats. Endocrinology 97, 898-907. 
Drouin, J. \& Labrie, F. (1976) Selective effect of androgens on FSH and $\mathrm{LH}$ release in anterior pituitary cells in culture. Endocrinology 98, 15281534.

Erickson, G.D. \& Hsueh, A.J.W. (1978) Secretion of 'inhibin' by rat granulosa cells in vitro. Endocrinology 103, 1960-1963.

Gay, V.L. \& Tomacari, R.L. (1974) Follicle Stimulating Hormone secretion in the female rat: cyclic release dependent on circulating androgens. Science, N.Y. 184, 75-76.

Gay, V.L., Midgley, A.R. \& Niswender, G.D. (1970) Patterns of gonadotrophin secretion associated with ovulation. Fedn Proc. Fedn Am. Socs exp. Biol. 29, 1880-1887.

Hage, A.J., Groen-Klevant, A.C. \& Welschen, R. (1978) Follicle growth in the immature rat ovary. Acta endocr., Copenh. 88, 375-382.

Hermans, W.P., van Leeuwen, E.C.M., Debets, M.H.M. \& de Jong, F.H. (1980) Involvement of inhibin in the regulation of follicle stimulating hormone concentrations in prepubertal and adult, male and female rats. J. Endocr. 86, 79-29.

Hopkinson, C.R.N., Daume, E., Sturm, G., Fritze, E., Kaiser, S. \& Hirschhäuser, C. (1977) Inhibin-like activity of bovine ovarian extracts in male and female rats. J. Reprod. Fert. 50, 93-96.

Juneja, H.S., Motta, M., Vasconi, F. \& Martini, L. (1977) Negative and positive effects of androgens on gonadotrophin release. In Androgens and Antiandrogens, pp. 127-135. Eds L. Martini \& M. Motta. Raven Press, New York.

Labrie, F., Lagacé, L., Ferland, L., Kelly, P.A., Drouin, J., Massicotte, J., Bonne, C., Raynaud, J.P. \& Dorrington, J.H. (1978) Interactions between LHRH, sex steroids and "inhibin" in the control of LH and FSH secretion. Int. J. Androl., Suppl. 2, 81-101.

Louvet, J.P., Harman, S.M., Schreiber, J.R. \& Ross, G.T. (1975) Evidence for a role of androgens in follicular maturation. Endocrinology 97, 366-372.

Mandl, A.M. \& Zuckerman, S. (1952) Cyclical changes in the number of medium and large follicles in the adult rat ovary. J. Endocr. 8, 341-346.

Marder, M.L., Channing, C.P. \& Schwartz, N.B. (1977) Suppression of serum follicle stimulating hormone in intact and acutely ovariectomized rats by porcine follicular fluid. Endocrinology 101, 1639-1642.

McCullagh, D.R. (1932) Dual endocrine activity of the testis. Science, N.Y. 76, 19-20.

Meijs-Roelofs, H.M.A., Uilenbroek, J.Th.J., Osman, P. \& Welschen, R. (1973a) Serum levels of gonadotrophins and follicular growth in prepuberal rats. In The Development and Maturation of the Ovary and its Functions, pp. 3-11. Ed. H. Peters. Excerpta Medica (I.C.S. No. 267), Amsterdam.

Meijs-Roelofs, H.M.A., Uilenbroek, J.Th.J., de Jong, F.H. \& Welschen, R. (1973b) Plasma oestradiol-17 $\beta$ and its relationship to serum FSH in immature female rats. J. Endocr. 59, 295-304.
Meijs-Roelofs, H.M.A., de Greef, W.J. \& Uilenbroek, J.Th.J. (1975) Plasma progesterone and its relationship to serum gonadotrophins in immature female rats. $J$. Endocr. 64, 329-336.

Miller, K.F., Wesson, J.A. \& Ginther, O.J. (1979) Changes in concentrations of circulating gonadotrophins following administration of equine follicular fluid to ovariectomized mares. Biol. Reprod. 21, 867-872.

Nequin, L.G., Alvarez, J. \& Schwartz, N.B. (1975) Steroid control of gonadotrophin release. J. Steroid Biochem. 6, 1007-1012.

Ojeda, S.R. \& Ramirez, V.D. (1972) Plasma level of LH and FSH in maturing rats: response to hemigonadectomy. Endocrinology 90, 466-472.

Schwartz, N.B. (1969) A model for the regulation of ovulation in the rat. Recent Prog. Horm. Res. 25, $1-43$.

Schwartz, N.B. \& Channing, C.P. (1977) Evidence for ovarian "inhibin": Suppression of the secondary rise in serum follicle stimulating hormone levels in proestrous rats by injection of porcine follicular fluid. Proc. natn. Acad. Sci. U.S.A. 74, 5721-5724.

Setchell, B.P., Davies, R.V. \& Main, S.J. (1977) Inhibin. In The Testis, vol. 4, pp. 189-238. Eds A. D. Johnson \& W. R. Gomes. Academic Press, New York.

Verjans, H.L., Cooke, B.A., de Jong, F.H., de Jong, C.M.M. \& van de Molen, H.J. (1973) Evaluation of a radioimmunoassay for testosterone estimation. $J$ Steroid. Biochem. 4, 665-676.

Welschen, R. (1973) Amounts of gonadotrophins required for normal follicular growth in hypophysectomized adult rats. Acta endocr., Copenh. 72, 137-155.

Welschen, R. \& Dullaart, J. (1974) Serum concentrations of follicle stimulating hormone and luteinizing hormone after unilateral ovariectomy in the adult rat. J. Endocr. 63, 421-422.

Welschen, R. \& Dullaart, J. (1976) Administration of antiserum against ovine FSH or ovine $\mathrm{LH}$ at pro-oestrus in the rat: effects on follicular development during the oncoming cycle. J. Endocr. 70, 301-306.

Welschen, R., Osman, P., Dullaart, J., de Greef, W.J., Uilenbroek, J.Th.J. \& de Jong, F.H. (1975) Levels of follicle stimulating hormone, luteinizing hormone, oestradiol-17ß and progesterone, and follicular growth in the pseudopregnant rat. J. Endocr. 64, 37-47.

Welschen, R., Hermans, W.P., Dullaart, J. \& de Jong, F.H. (1977) Effects of an inhibin-like factor present in bovine and porcine follicular fluid on gonadotrophin levels in ovariectomized rats. $J$. Reprod. Fert. 50, 129-131.

Welschen, R., Dullaart, J. \& de Jong, F.H. (1978) Interrelationships between circulating levels of estradiol-17 $\beta$, progesterone, FSH and $\mathrm{LH}$ immediately after ULO in the cyclic rat. Biol. Reprod. 18, 421-427. 